\title{
Fertility Intentions and Views on Gender Roles: Russian Women in Estonia from an Origin-destination Perspective*
}

\author{
Allan Puur, Hanna Vseviov, Liili Abuladze
}

\begin{abstract}
In this article we investigate fertility intentions of Russian women in Estonia from an origin-destination perspective. Russian migrants to Estonia and their descendants are compared with women in the sending and host countries in order to identify similarities and differences in intended transitions to first, second and third births. The study is based on the Estonian and Russian Generations and Gender Surveys, which were conducted in 2004/2005, and employs logistic regression models. The dependent variables are intentions to become a mother, to have a second child, or to have a third child. The hypotheses for the study are mainly derived from the adaptation, cultural maintenance, and selection (characteristics) perspectives. We also incorporate attitudes towards gender roles into the models, which have proven to be a salient factor in shaping childbearing intentions, but have seldom been considered in studies of migrant fertility.

Our results lend support to both the adaptation and cultural maintenance perspectives. In accord with the latter, the similarity between the childbearing intentions of Russian migrants and their descendants in Estonia and those of their counterparts in Russia suggests that socialisation to the ethnic subculture has prevailed over the influence of the host society. We attribute this outcome to contextual features that have retarded integration processes. By contrast, we observe that proficiency in the host country language, residence in areas where the host population constitutes a large majority and having a native partner significantly contribute to the adaptation of migrants' intentions to have another child to those of the host population. These results provide support to the adaptation argument. Finally, our study reveals a positive association between egalitarian views on gender roles and women's intentions to have another child. However, variation in gender role attitudes accounts for a relatively minor part of the difference in intended fertility between the groups addressed in this study.
\end{abstract}

Keywords: Migrant fertility · Descendant $\cdot$ Gender role attitudes · Integration · Estonia $\cdot$ Russia

This article belongs to a special issue on migrant fertility.

Federal Institute for Population Research 2019 BY $-5 A$
URL: www.comparativepopulationstudies.de DOI: 10.12765/CPoS-2019-04en URN: urn:nbn:de:bib-cpos-2019-04en5 


\section{Introduction}

For a number of reasons, recent decades have witnessed rapidly growing scholarly interest in migrant fertility. First of all, migrants contribute to an increasing degree to aggregate national fertility levels, thus influencing the demographic prospects of the host society. It is known that the proportion of total births to immigrant parents has increased markedly in many European countries (Sobotka 2008; Lanzieri 2011). Furthermore, in demographic and sociological studies, the childbearing patterns of migrants are regarded as an important indicator of integration into the host society (Coleman 1994; Algan et al. 2012). Studies generally find that migrant fertility gradually converges with levels that are characteristic of the host population, although for some immigrant groups differences may persist across generations (Milewski 2007; Garssen/Nicolaas 2008; Scott/Stanfors 2011; Dubuc 2012; Krapf/Wolf 2015). Descendants of migrants may have depressed, similar or elevated fertility levels compared with the native population of the host countries, depending on the context and country of parental origin (Kulu et al. 2017; Andersson et al. 2017). Last but not least, the experience of international migrants provides valuable insight into the role of structural and cultural factors that are assumed to shape demographic outcomes. For this reason, research on migrant fertility adds to an improved understanding of how economic and cultural factors interact and influence childbearing decisions in contemporary societies.

In the $21^{\text {st }}$ century, research on migrant fertility has drawn its evidence increasingly from retrospective surveys. Since then, analyses applying event history techniques have generated much valuable knowledge (Kulu/Milewski 2007; de Valk/ Milewski 2011). Life-course data and new analytical approaches have allowed scholars to disaggregate fertility patterns and investigate the interplay between migration and childbearing with much greater precision than previously feasible. In their review article, Kulu/Gonzàlez-Ferrer (2014) have provided a useful summary of recent individual-level studies and outlined several directions for the further development of research on the fertility of immigrants and ethnic minorities. Among other elements, they have pointed to the need to undertake more comparative research, not only across different groups of migrants, but also across different host countries, in order to gain a better understanding of how institutional and policy contexts shape the lives of immigrant families and their descendants.

In this article, however, we take a different route. We seek to complement the existing literature on migrant fertility by drawing our evidence from fertility intentions rather than fertility histories. Although information on fertility preferences is routinely collected as part of many demographic surveys, and a large body of literature exists on intended fertility, childbearing intentions have seldom been addressed in the immigration context (Nedoluzhko 2012; Marczak 2013). The motivation to investigate intended fertility stems from the fact that intentions form an important link in the chain leading to the decision to have a child, and are seen as a major determinant of reproductive behaviour (Schoen et al. 1999; Philipov/Bernardi 2011). Furthermore, fertility intentions reflect childbearing norms shared and reproduced by various social and cultural groups to which individuals belong. This makes inten- 
tions particularly useful for studying adaptation processes by which immigrants and their descendants may switch from the norms of their country of origin to those of the host country. Finally, focusing on fertility intentions allows us to incorporate in the analysis covariates pertaining to respondents' attitudes, which is not feasible in studies based on retrospectively collected childbearing histories because reliable attitudinal information is almost impossible to obtain retrospectively. Furthermore, we include in the analysis non-migrants (or "stayers") in the country of origin. Although various researchers have recommended this approach (Schoenmaeckers et al. 1999; Glick 2010; Lessard-Phillips et al. 2017), it has been implemented only in a few European studies due to data constraints (Nauck 2007; White 2011; Baizán et al. 2014; Krapf/Wolf 2015; Baykara-Krumme/Milewski 2017; Klimek 2017; Wolf/Mulder 2018).

More specifically, the aim of this study is to investigate the childbearing intentions of Russian emigrants and their descendants in Estonia relative to the sending populations (Russians in Russia) and host populations (Estonians). The cohorts included in the study exhibited systematically higher fertility rates in Estonia than in Russia. We seek evidence regarding the extent to which the intentions of Russian women in Estonia of having first, second and third births compare with those of the countries of destination and origin. We are also interested in individual and contextual factors that may influence the childbearing intentions of migrants and their descendants.

The study adds to research on migrant fertility in multiple ways. The first contribution stems from the use of a bi-national sample based on pooled data from the Estonian and Russian Generations and Gender Surveys (2004/2005). These data allow us to examine the fertility intentions of migrants and their descendants from the perspective of both the sending and host countries, which is seldom feasible in studies of international migration. These are the only two countries participating in the Generations and Gender Programme for which such analysis is feasible. Second, we are able to incorporate into the models variables that have rarely been considered in analyses of migrant fertility. In particular, this contribution relates to attitudes towards gender roles, which have been proven in a number of studies to have a significant influence on childbearing intentions (Kaufman 2000; Puur et al. 2008; Miettinen et al. 2011). In addition, our study provides insights into the role of language proficiency and the spatial concentration of migrants, both of which are important from a policy perspective. Finally, with regard to host societies, European research on the fertility patterns of migrants and their descendants has dealt overwhelmingly with the northern, western and southern parts of the continent. In contrast, studies on groups involved in large-scale population movements in Eastern Europe are relatively rare (Jasilioniene et al. 2014), and by focusing on Russians in Estonia, our study contributes to a more comprehensive account. Russians comprise the third largest immigrant group originating from third countries in the context of the EU (Eurostat 2018). However, there is substantially less research on their demographic patterns compared with other larger groups (e.g. Turks and Moroccans). 


\section{Theoretical considerations and previous findings}

Several theoretical frameworks have been developed to account for fertility patterns among migrants who move from one societal context to another (for an overview, Milewski 2010; Kulu/Gonzáles-Ferrer 2014). This study is guided by the adaptation, cultural maintenance, and selection (characteristics) perspectives. Our analysis is focussed on fertility intentions among migrants and their descendants, who were either born in the host country or had arrived there several years before our survey data were collected. This renders frameworks that concentrate on the short-term effects of the move (disruption, interrelation of events) largely irrelevant for the purposes of our study, which focuses on the long-term perspective.

According to the adaptation perspective, the childbearing behaviour of migrants gradually comes to resemble the dominant behaviour of the destination population (Kulu 2005). The adaptation perspective is also applicable to the descendants of migrants if the transition to host country behaviours extends beyond the first generation. The literature identifies several mechanisms that support the process of convergence with the fertility patterns of the host society (Rumbaut/Weeks 1986; Frank/Heuveline 2005). Through exposure to the host society and social learning, migrants are thought to adopt the norms and values prevailing in the host society (Hirschman 1983; Alba 2005). In addition, the social and economic conditions in the receiving country are believed to affect the cost of childbearing (Hotz et al. 1997), levelling out differences between migrants and the host country natives.

Abbasi-Shavazi and McDonald (2002) formulated the theory of cultural maintenance, which is based on the assumption that parents of migrants transmit their values, norms and attitudes to their children. If the latter pass the inherited values, norms and attitudes on to subsequent generations, fertility patterns inherited from the country of ancestry may persist in the host country over a considerable period of time. As migrants and their descendants are exposed to the norms and family behaviour of their parents, rather than to those of the host society, intergenerational transmission can be regarded as a central mechanism that enables cultural maintenance. The latter premise makes cultural maintenance similar to the socialisation perspective, which emphasises the importance of the social environment of migrants and their descendants during childhood, and assumes that it has a lasting impact over the life course (Andersson 2004; Kulu/Milewski 2007). Furthermore, the idea of cultural maintenance can be connected to family systems as constructs that integrate norms, values and practices associated with the organisation of family ties (Reher 1998). In a recent study, for instance, Mönkediek and Bras (2016) drew attention to a link between family systems and fertility intentions, with the effects of family systems varying between intentions to start and to extend a family.

Both the cultural maintenance and adaptation perspectives are widely supported by empirical findings. The absence of complete convergence of migrant fertility behaviour with that of the host population, even after controlling for compositional effects, lends support to the cultural maintenance perspective. In Europe, larger differences are usually characteristic of migrant groups from high-fertility contexts (Andersson/Scott 2007; Milewski 2011; Kulu et al. 2017). Evidence in favour of the 
cultural maintenance perspective is also provided by studies that directly incorporate origin-country fertility levels into the models (Cygan-Rehm 2011; Stichnoth) Yeter 2013). In support of the adaptation argument, a number of authors have reported that close similarity to host-country fertility levels may be achieved within a relatively short time after the arrival of migrants in the destination country (Ford 1990; Mayer/Riphahn 2000; Andersson 2004). The intermediate position of the descendants of migrants has been corroborated by many studies (Abbasi-Shavazi) McDonald 2000; Milewski 2007; Parrado/Morgan 2008; Dubuc 2012; Scott/Stanfors 2011; Krapf/Wolf 2015). This suggests that adaptation and cultural maintenance are complementary rather than mutually exclusive, and indicates that childbearing decisions among the descendants of migrants are shaped by both the host society in which they grew up and the values and norms of their ancestors. Consequently, the fertility behaviour of the descendants of migrants is dependent on the relative strength of these rival influences.

Studies of fertility patterns among migrants and their descendants that take the origin-destination approach must also consider the selection and characteristics perspectives. The selection perspective posits that migrants are systematically selected based on various characteristics that may produce fertility patterns that are distinct from those of the sending population and more similar to those of the host society (Macisco et al. 1970; Goldstein/Goldstein 1984). Selection can be based on observable characteristics such as education, family background, etc., but migrants may also be selected according to less obvious features. Empirical research provides evidence for both types of selection (Lievens 1999; Lindstrom/Saucedo 2002; Bagavos et al. 2008; Mussino/Strozza 2012; Wolf/Mulder 2018). According to the characteristics perspective, the composition of migrant groups in terms of socioeconomic or cultural characteristics could be partly or wholly responsible for fertility differentials between the former and the latter (Bean et al. 2000; Hill/Johnson 2004). The characteristics of migrants (both observed and unobserved) may be transmitted to the second generation by their parents (Frank/Heuveline 2005). Therefore, in order to properly assess the fertility patterns of migrants and their descendants, their compositional differences in relation to the sending and receiving populations should be considered.

Although previous research has produced much valuable knowledge on the fertility of migrants and their descendants, there are some noticeable limitations. First of all, the above studies have focussed on family size or timing of births, without considering the childbearing intentions of migrants and their descendants. Very few studies have looked into migrants' fertility plans (Klimek 2017, Kraus/Castro 2018). In the demographic literature, fertility intentions have attracted considerable scholarly attention as they are deemed to be important predictors of future childbearing trends and differentials (Westoff 1990; Bongaarts 2001). In the $21^{\text {st }}$ century, a new wave of research into fertility intentions has emerged in Europe and other Western countries due to growing concerns about low fertility rates and the gap between intended and actual fertility (Philipov 2009; Spéder/Kapitány 2009). At the same time, scholars have expressed scepticism about the predictive validity of reproductive intentions, on both the individual and aggregate levels (Quesne/-Vallée/Morgan 2003). 
In industrialised countries, unexpected obstacles, health difficulties, problems with conception, etc. tend to combine so that individuals rarely have as many children as they may have intended. Yet, as Morgan and Rackin (2010) argue, this does not make research on fertility intentions irrelevant; rather, discrepancies between intended numbers of children and observed fertility provide opportunities to study constraints on fulfilling intentions.

Another significant drawback of existing research on migrant fertility relates to the explanatory variables. As the overwhelming majority of recent studies on migrant fertility have drawn their evidence from retrospective childbearing histories, the authors of these studies have rarely been able to explicitly consider attitudes, norms and values, which are known to play a prominent role in explaining contemporary fertility patterns and other aspects of family dynamics (Fernandez/Fogli 2006; Lesthaeghe 2010). In this study, we seek to contribute to filling this void by incorporating attitudes towards gender roles into the analysis. The consideration of gender role attitudes is motivated by the gender equity theory. According to $\mathrm{Mc}$ Donald (2000), fertility in contemporary societies is influenced by levels of gender equity experienced by women in the public and private spheres. He regards the perception of two central attributes of equity - fairness and opportunity - as particularly important to the connection between gender equity and fertility (McDonald 2013). Several authors have further developed this framework by introducing the idea of a two-stage gender revolution (Billari/Esping-Andersen 2015; Goldscheider et al. 2015). According to their view, in the first stage of the gender revolution, families experience considerable pressure, as women increasingly assume roles in the public sphere, while men share caregiving and domestic tasks in the private sphere to a much lesser degree, leading to a severe reduction in fertility rates. In the second stage, however, families are empowered as men begin to contribute to the unpaid work of caring for the family, bringing fertility closer to replacement level.

In recent years, a variety of empirical studies have examined the connection between gender equity and fertility intentions. The results vary considerably, not least because of differences in the ways in which gender equity is operationalised (Goldscheider et al. 2010; Mills 2010; Neyer et al. 2013). As regards attitudes towards gender roles, Kaufman (2000) found that gender-egalitarian attitudes are associated with an increased likelihood of intention to have a/another child. This finding was corroborated by Puur et al. (2008), who, based on evidence from eight European countries, reported that men with egalitarian attitudes have higher fertility aspirations than their traditional counterparts. However, these findings were contested by Westoff and Higgins (2009), who demonstrated that the positive connection between egalitarian attitudes and fertility intentions depends significantly on the measures employed. Miettinen et al. (2011) found a U-shaped association among Finnish men, showing that both traditional and egalitarian attitudes raise men's expected fertility; however, their results for women were somewhat more ambiguous.

Previous studies have provided evidence of individual and contextual factors that can promote (or hinder) the convergence of the fertility behaviour of migrants and their descendants with that of the host society. Factors that have proven to be salient in this regard include proficiency in the host country language Kahn 1988; 
Forste/Tienda 1996; Kulu/Hannemann 2016), the spatial concentration of migrants or ethnic minorities (Brewster 1994; Wilson/Kuha 2016), and partnering with host country natives (Andersson/Scott 2007; Scott/Stanfors 2011; Stichnoth/Yeter 2013). We study the extent to which these factors influence fertility intentions.

In the following sections, we apply the above theoretical perspectives to the study of childbearing intentions of Russian emigrants and their descendants in Estonia. In order to set the stage for the formulation of hypotheses, the next section briefly outlines the characteristics of the migrant group and fertility trends in the sending and host countries.

\section{The context}

Before the Second World War, the historical Russian minority constituted 8 percent of the total population of Estonia, but war-time population losses that took a particularly heavy toll on minority groups, coupled with the transfer of border areas with an ethnically mixed population from Estonia to Russia in late 1944, decreased the proportion of Russians to less than 3 percent. The annexation of the Baltic countries into the Soviet Union was followed by large-scale migration from Russia to Estonia, which persisted until the late 1980s. By the end of the 1980s, the proportion of (ethnic) Russians had increased to 30 percent (Katus et al. 2002). Migration to Estonia and the other Baltic countries was driven to an important extent by Soviet economic policies and somewhat higher living standards that made the Baltic region attractive to labour migrants, professionals and manual workers (Kahk/Tarve/ 1997). The restoration of Estonia's independence brought large-scale immigration to a halt and resulted in a wave of return migration in the 1990s. Since then, the volume of the migration flow between Russia and Estonia has been moderate, and the proportion of ethnic Russians has stabilised at one quarter of the total population (Tammur et al. 2017). According to the latest census, post-war migrants to Estonia comprised 38 percent of all Russians residing in the country, while most of the remaining 62 percent were the descendants of Russian migrants born in the host country.

As regards fertility trends in the host country and country of origin, until the 1960s early demographic modernisation accounted for noticeably lower fertility levels in Estonia relative to the Russian Federation (Katus 2000; Zakharov 2003). However, in the late 1960s fertility levels in the two countries converged. In Estonia, a moderate rise in fertility rates occurred, which returned fertility close to replacement level, while in Russia, the fertility transition came to an end with the total fertility rate (TFR) stabilising slightly below replacement (Table 1). As a consequence, the difference in fertility levels between the countries reversed, and in the 1970s and 1980s Estonia exhibited slightly higher TFRs than Russia. In both countries, a major interruption in fertility trends occurred in the 1990s, when birth rates sharply decreased all over Eastern Europe. In Estonia, the period TFR reached its lowest point in 1998, and one year later in Russia. In the early $21^{\text {st }}$ century, however, fertility rates gradually recovered in both countries (Puur/Klesment 2012; Frejka/Zakharov 2012). Estimates of completed cohort fertility indicate that Estonia's moderate fertil- 
Tab. 1: Total period fertility rate and completed cohort fertility rate, Russians in Estonia, Estonia and Russia

\begin{tabular}{lcccccc}
\hline Period & Estonia & Russia & Birth cohort & Estonia & $\begin{array}{c}\text { Russians } \\
\text { in Estonia }\end{array}$ & Russia \\
\hline $1955-1959$ & 2.00 & 2.72 & $1925-1929$ & 1.78 & 1.76 & 2.21 \\
$1960-1964$ & 1.95 & 2.41 & $1930-1934$ & 1.78 & 1.69 & 2.17 \\
$1965-1969$ & 1.97 & 2.06 & $1935-1939$ & 1.79 & 1.67 & 2.04 \\
$1970-1974$ & 2.13 & 2.01 & $1940-1945$ & 1.83 & 1.64 & 1.93 \\
$1975-1979$ & 2.04 & 1.96 & $1945-1949$ & 1.92 & 1.63 & 1.84 \\
$1980-1984$ & 2.10 & 1.99 & $1950-1954$ & 1.97 & 1.68 & 1.89 \\
$1985-1989$ & 2.21 & 2.11 & $1955-1959$ & 2.02 & 1.67 & 1.88 \\
$1990-1994$ & 1.69 & 1.59 & $1960-1964$ & 1.96 & 1.59 & 1.76 \\
$1995-1999$ & 1.33 & 1.25 & $1965-1969$ & 1.85 & 1.53 & 1.64 \\
$2000-2004$ & 1.37 & 1.28 & $1970-1974$ & 1.83 & 1.54 & 1.59 \\
\hline
\end{tabular}

Note: Reliable long-term time series of period fertility rates for Russians in Estonia are not available. As the data used in this study were collected in $2004 / 2005$, fertility rates for subsequent years are not included in the table.

Source: Myrskylä et al. 2013, Statistical Office of Estonia 2018, Zakharov 2008, 2017

ity advantage over Russia extends to the younger generations whose family formation occurred in the 1990s and 2000s (Myrskylä et al. 2013). In the period when the data used in this study were collected, the mean age at first birth was 25.2 in Estonia and 24.1 in Russia; the mean age at any birth was 27.8 and 25.9 years, respectively.

Evidence from analyses of retrospective childbearing histories suggests that in accord with the cultural maintenance perspective, the fertility pattern of Russian migrants and their descendants in Estonia is quite similar to that of their country of origin (Puur et al. 2017). In particular, this is reflected in a somewhat earlier entry into parenthood and lower progression rates to second and higher-order births relative to Estonians. This has been explained by slow integration into the host society, which is to a significant extent the legacy of the Soviet era. Despite progress made since the 1990s, only two-fifths of Russians in Estonia reported proficiency in the host country language at the last census. The rates of intermarriage between the migrant and host populations are relatively low, with no marked increase across migrant generations (Puur et al. 2018). The degree of integration has been influenced by several factors, including a high concentration of Russians in certain regions of the country and the linguistic division of the educational system. Nonetheless, the situation is gradually improving among the younger generations. Proficiency in the host country language among younger Russians exceeds 70 percent, with no marked difference between migrant generations, and shifts towards improved integration are occurring in other domains as well (Puur et al. 2016; Realo 2017).

To the best of our knowledge, no systematic evidence exists with regard to gender role attitudes among Russian migrants and their descendants in Estonia. How- 
ever, a recent study on mixed partnerships by Rahnu et al. (2015) reported that ethnic minority women in Estonia (more than 90 percent of whom are Russians, Ukrainians and Byelorussians) tend to express less support for gender equality than their majority counterparts. ${ }^{1}$ It is plausible that this finding can be extended to Russians, as they constitute the largest minority group in the country. As regards the comparison of the sending and host countries, recent research based on the European Social Survey suggests that egalitarian gender role attitudes are more prevalent in Estonia than in Russia (Pessin/Arpino 2018). Although the two countries shared a similar institutional context with respect to economic and social policies for almost five decades, evidence from comparative studies suggests that noticeable differences in family practices, rooted in cultural norms, persisted (Puur et al. 2012; Rahnu 2016). Russians in Estonia tend to have more traditional views on gender roles than Estonians. The most recent gender-equality monitoring (Turu-uuringute AS 2016) shows that while Russians in Estonia express less support for gender equality, Russian women are more often dissatisfied with the status quo, and report a more severe work-family conflict than Estonians (Espenberg et al. 2013). A few recent studies have examined fertility patterns among migrant groups in Estonia (Abuladze et al. 2013; Billingsley et al. 2014; Puur et al. 2017) but there are virtually no analyses of childbearing intentions among these groups. This study seeks to contribute to filling this void by focusing on Russians in Estonia, and comparing their fertility intentions with the populations of the sending and host countries.

\section{$4 \quad$ Research aim and hypotheses}

A review of the literature and contextual features described in the previous sections lead us to the formulation of the following hypotheses.

We begin by considering inter-group differences, including all Russian women living in Estonia as a single group. Our first hypothesis (H1) is that the fertility intentions of Russian women in Estonia would be more similar to those of their country of origin than to those prevailing in the host society. The hypothesis draws on the cultural maintenance perspective, according to which migrant-origin groups may preserve fertility norms that bear resemblance to those of their country of origin and differ from those of the country of destination. This expectation arises from contextual features, including the large size of the group addressed in our study, its spatial concentration and the linguistically divided school system.

In the next step, we address intra-group differences between Russian migrants and their descendants in Estonia. Our second hypothesis $(\mathrm{H} 2)$ posits that the fertility intentions of the descendants of Russian migrants in Estonia would resemble those of the first generation, in accord with the cultural maintenance perspective. Given

1 For instance, 27 percent of ethnic minority women agreed with the statement that in times of job scarcity, men should be given preference over women in the labour market, whereas only 8 percent of Estonian women agreed with the statement. 
their relatively slow integration into the host society and the contextual features discussed above, the descendants of migrants may be socialised into the sub-culture of the migrant group and follow the fertility norms of their parents.

Further, our third hypothesis (H3) anticipates that differences between the groups included in this study would vary by parity. Guided by recent findings pertaining to fertility transitions among Russians in Estonia (Puur et al. 2017), we expect limited or no difference in intentions to enter parenthood among childless women irrespective of the group to which they belong. However, we expect significant intergroup variation in intentions to have a second and third child, with higher likelihood of second- and third-birth risks among the host population, as described in the previous section of the article.

Our fourth hypothesis $(\mathrm{H} 4)$ anticipates that controlling for the relationship between more egalitarian views on gender roles and the intention to have a/another child may decrease the fertility differentials between Russians in Estonia and the host population. This expectation draws on the gender equity theory as well as the empirical findings discussed in the previous sections.

Our fifth hypothesis $(\mathrm{H} 5)$ is that increasing integration into the host society would bring about the convergence of the fertility intentions of Russian migrants and their descendants in Estonia with the host population pattern. Finding support for this hypothesis would be important to provide insights into the mechanisms that underpin the adaptation perspective, and to obtain a better understanding of the demographic implications of integration processes.

Finally, this study is also expected to cast light on the role of selection and the characteristics of migrants and their descendants. The research on migrant fertility reviewed earlier in the article indicates that the socio-economic profiles of migrants and their descendants may be different from those of the sending or host populations. Therefore, our sixth hypothesis $(\mathrm{H} 6)$ expects that the specificity of fertility intentions among migrants and their descendants would be diminished when these differences are taken into account. However, we do not anticipate a change in intergroup differences related to selectivity, or expect that the compositional differences would be substantial. This expectation arises, inter alia, from the large flow of migration from Russia to Estonia that persisted over several decades and comprised migrants with diverse social backgrounds.

\section{Data, analytical approach and variables}

Our analyses are based on the national surveys conducted in Estonia and Russia in 2004-2005 within the framework of the Generations and Gender Programme. ${ }^{2}$ Both surveys applied the life-course approach and collected detailed retrospective histories of childbearing, and formation and dissolution of partnerships. In addition, the

$\overline{2}$ Our study makes use of the first wave of the Russian GGS and the sole wave of the Estonian GGS. 
surveys asked questions about the respondents' intentions in a number of domains, and concerned a variety of issues that are of great importance for explaining demographic behaviour, such as education, economic circumstances, housing, social networks, health, subjective well-being and attitudes (Vikat et al. 2007).

Comparability of the data was achieved through common guidelines for the survey design, and a standard questionnaire and survey instruments (UNECE 2005). The surveys were based on nationally representative probability samples of the resident population. In the Estonian GGS, respondents were selected from the population enumerated in the 2000 census, using a single-stage random procedure; a total of 7,855 women and men born between 1924 and 1983 were interviewed, with a response rate of 70 percent. The Russian survey employed a multi-stage sampling procedure resulting in 11,261 interviews with men and women in the 1924-1987 birth cohorts; the overall response rate for the Russian GGS was 44 percent. Further information on the data sources is available from methodological publications (Independent Institute for Social Policy 2004; Katus et al. 2008).

In this article, we analyse childbearing intentions among Russians who have settled in Estonia, against the background of Estonians in the host country and Russians in the country of origin. These sub-groups of our study population were defined according to self-declared ethnicity, which was available from both surveys (UNECE 2005). Russians in Estonia were divided into migrants (the first generation), who were born abroad, and the descendants of migrants, who were born in the host country but whose parents (or all grandparents) had migrated to Estonia. ${ }^{3}$ Following an approach frequently taken in the study of fertility intentions, we focus on women aged 20-44 (born from 1960 to 1983), whose childbearing decisions are of great importance for contemporary fertility levels. A small number of respondents who were pregnant at the time of the surveys, who declared themselves not fecund, or did not report their fertility intentions, were excluded from the analysis. In total, our working sample comprises 4,117 women, including 1,388 Estonians (34 percent of the sample), 535 Russian migrants and their descendants living in the host country (13 percent) and 2,194 Russians in the country of origin (53 percent). Of the Russian women in Estonia included in our study, 137 were migrants and 398 descendants of migrants born in the host country.

In the GGS surveys, fertility intentions were addressed by two questions. Respondents were first asked about their desire to have a/another child during the next three years. Those who did not intend to have a child in the next three years were asked a follow-up question regarding whether they intended to have any (more) children in the future. The first question is an indicator of short-term fertility intentions; combining the two questions provides an account of lifetime fertility intentions. Both short-term and lifetime intentions are used in contemporary fertility research for various purposes (Philipov 2009; Balbo et al. 2013). Short-term intentions

3 In our study, the descendants of migrants consist mostly of second-generation migrants (82 percent), plus a small number of third-generation migrants. Second generation migrants were defined as those who were born in the host country and who have at least one parent born in a foreign country. 
mimic the operative decisions that women or couples make. Scholarly interest in short-term fertility intentions has increased with the implementation of panel surveys, such as the GGS, in which the actual realisation of short-term intentions can be analysed. By contrast, lifetime fertility intentions allow for the fact that in addition to positive and negative decisions for the next 2-3 years, postponement can be a viable family formation strategy, particularly among younger and non-partnered women. Philipov et al. (2006: 293) refer to lifetime fertility and short-term fertility intentions as "intentions on whether and when to have a child". As we are primarily interested in the differences in the quantum of intended childbearing, we draw on lifetime intentions in constructing our dependent variable. ${ }^{4}$

Table 2 presents the proportions of women according to their childbearing intentions, disaggregated by origin-destination groups and parity. Overall, Russian women living in Estonia exhibit intentions of having a/another child that closely match those of their counterparts in the country of origin (Russia) and fall short of the respective intentions of the host population (Estonians). The evidence presented in the table further suggests that the observed pattern is wholly driven by differences in childbearing intentions among parous women. By contrast, the proportion of childless women who reported their intention to have at least one child appears to be closely similar across our origin groups. The lower proportion of women intending to have a/another child among first-generation Russian migrants (not shown in the table) stems mainly from their older age structure relative to the other groups included in the study.

In order to compare childbearing intentions among the origin-destination groups included in the study, we estimated logistic regression models for all women and women with different parities (childless, one child, two children). For each parity, we fitted a series of models to monitor the change in the effect of the main independent variable (origin-destination group) as other covariates were added in a stepwise procedure. The first model (M1) included only the main independent variable, namely the origin groups. In the second model (M2), controls for demographic characteristics such as age of the respondent and partnership status (married/cohabiting, no partner) were added; in the models for all women, M2 also included the number of children already born. Model M3 added a control for type of settlement (urban, rural), and Model M4 included an additional control for educational attainment distinguishing basic education (ISCED 1-2), secondary education (ISCED 3-4) and tertiary education (ISCED5-6). In the preliminary analysis, we experimented with a few additional control variables (employment status, number of siblings) but none of them noticeably altered the effect of our main independent variable. The selection of control variables was guided by previous studies on fertility intentions (Philipov

\footnotetext{
4 The dependent variable is dichotomous, with answers "definitely yes" and "probably yes" coded as 1, and answers "definitely no" and "probably no" coded as 0. Following a conservative approach, the "do not know" answers were merged with negative intentions (code 0). This is a common procedure in analyses of fertility intentions (e.g. Puur et al. 2008; Miettinen et al. 2011) that prevents overstating the intention to have a/another child.
} 
Tab. 2: Number of respondents and childbearing intentions. Russians in Estonia, sending and host populations, women aged 20-44

\begin{tabular}{lrcr}
\hline Parity and population group & $\begin{array}{c}\text { Number of } \\
\text { respondents }\end{array}$ & $\begin{array}{c}\text { Intention to have } \\
\text { a/another child, percent } \\
\text { Yes }\end{array}$ & No \\
\hline Al/ women & & & 53.9 \\
Russians in Russia & 2,194 & 46.1 & 53.3 \\
Russians in Estonia & 535 & 46.7 & 45.7 \\
Estonians & 1,388 & 54.3 & 10.8 \\
Parity 0 & & & 9.9 \\
Russians in Russia & 407 & 89.2 & 10.6 \\
Russians in Estonia & 141 & 90.1 & 46.1 \\
Estonians & 377 & 89.4 & 55.6 \\
Parity 1 & & & 29.9 \\
Russians in Russia & 989 & 53.9 & \\
Russians in Estonia & 214 & 44.4 & 84.8 \\
Estonians & 338 & 70.1 & 83.6 \\
Parity 2 & & & 70.9 \\
Russians in Russia & 677 & 15.2 & 16.4 \\
Russians in Estonia & 159 & 29.1 & \\
Estonians & 447 & & \\
\hline
\end{tabular}

Note: Russians in Estonia include first-generation migrants and descendants of migrants.

Source: Estonian and Russian GGS 2004-2005, own calculations

et al. 2006; Puur et al. 2008; Miettinen et al. 2011) and migrant fertility (Kulu et al. 2017; Puur et al. 2017).

Table 3 presents descriptive statistics of the socio-demographic control variables by origin-destination group. Chi-square tests confirmed that inter-group differences are significant for all the characteristics included in the table ( $p$-values varying from 0.000 to 0.04 ). The largest contrast is seen in the type of settlement, with only 6-7 percent of Russian women in Estonia residing in rural areas.

With regard to views on gender roles, we use information derived from the GGS module on value orientation and attitudes, which, among other themes, included questions about attitudes towards the roles of men and women. For the purposes of this study, three questionnaire items were used: i) "In a couple it is better for the man to be older than the woman"; ii) "Looking after the home or family is just as fulfilling as working for pay"; iii) "When jobs are scarce, men should have more 
right to a job than women". ${ }^{5}$ Respondents were asked to express their agreement or disagreement with each statement. The answers were recorded on a five-point Likert scale, whereby 1 signified strong agreement and 5 strong disagreement with the statement. In this study, higher values indicate greater support for a more egalitarian sharing of authority and family responsibilities, and provision of income, as opposed to the gender roles characteristic of the more traditional breadwinnerhomemaker model. It should be noted that these statements have a general, impersonal character, which is designed to limit the influence of different life situations, and facilitate comparability across sub-groups of the population. Likewise, general attitudes are considered less likely to be biased towards social desirability (Turner) Martin 1984; Hakim 2005).

For the analysis, we created a composite index from the responses to the three abovementioned questionnaire items, with the score ranging from 3 to 15 . The minimum score represents complete acceptance of a more traditional division of gender roles; the maximum score indicates that respondents expressed more egalitarian views and stated a strong disagreement with a traditional division of gender roles. Based on the index, respondents were classified as having traditional views on gender roles if they scored 7 points or less. If their score amounted to 12 points or more, they were classified as having egalitarian views; respondents with scores ranging from 8 to 11 points were included in an intermediate group. The descriptive statistics presented in Table 3 reveal a significant difference in the attitudes between the population groups included in our study. The acceptance of a traditional division of gender roles is strongest among women in the country of origin (Russia), while egalitarian views appear to be most prevalent among women native to the host country (Estonia). Against that background, Russian migrants to Estonia and their descendants occupy an intermediate position. To ascertain whether the observed variation in attitudes towards gender roles may be associated with differences in fertility intentions between origin-destination groups, we estimated an additional model (M5), which added variables based on our composite index to a complete set of socio-demographic controls.

Finally, we estimated a few additional models (M6, M7 and M8) in order to investigate whether the degree of integration of Russian migrants and their descendants into the host society is associated with convergence of their fertility intentions with those of Estonians. These models include proficiency in the host country language, the proportion of ethnic Estonians in the municipality of residence, and having an Estonian partner. These models are estimated for Russian women in Estonia who have at least one child, motivated by the fact that the difference in fertility intentions between Russians in Estonia and the host population mainly relates to the progression beyond first birth, as will be shown in the following section.

\footnotetext{
5 In preliminary analyses we considered a slightly longer list of attitudinal questions. The final selection was based on two criteria: the extent to which the items differentiated the origindestination groups, and their relationship with fertility intentions.
} 
Tab. 3: Descriptive statistics for control variables included in the models.

Russians in Estonia, sending and host populations, women aged 20-44

\begin{tabular}{|c|c|c|c|c|}
\hline Variables & $\begin{array}{c}\text { Russians in } \\
\text { Russia }\end{array}$ & $\begin{array}{c}\text { Russians in } \\
\text { Estonia }\end{array}$ & Estonians & $x^{2}$ test \\
\hline \multicolumn{5}{|l|}{ Age } \\
\hline $20-24$ & 15.92 & 18.50 & 16.05 & \multirow{5}{*}{0.040} \\
\hline $25-29$ & 20.68 & 19.63 & 19.68 & \\
\hline $30-34$ & 22.98 & 20.00 & 20.82 & \\
\hline $35-39$ & 20.82 & 16.64 & 19.95 & \\
\hline $40-44$ & 19.60 & 25.23 & 23.50 & \\
\hline \multicolumn{5}{|l|}{ Number of children } \\
\hline 0 & 27.16 & 26.36 & 18.64 & \multirow{4}{*}{0.000} \\
\hline 1 & 24.35 & 40.00 & 45.09 & \\
\hline 2 & 32.20 & 29.72 & 30.77 & \\
\hline 3 or more & 16.28 & 3.93 & 5.50 & \\
\hline \multicolumn{5}{|l|}{ Partnership status } \\
\hline Living with a partner & 65.2 & 63.6 & 69.7 & \multirow{2}{*}{0.006} \\
\hline No partner & 34.8 & 36.4 & 30.3 & \\
\hline \multicolumn{5}{|l|}{ Settlement type } \\
\hline Urban & 74.5 & 93.8 & 64.2 & \multirow{2}{*}{0.000} \\
\hline Rural & 25.5 & 6.2 & 35.8 & \\
\hline \multicolumn{5}{|l|}{ Educational attainment } \\
\hline Basic & 10.8 & 8.4 & 9.9 & \multirow{3}{*}{0.000} \\
\hline Secondary & 64.0 & 75.0 & 70.0 & \\
\hline Tertiary & 25.5 & 16.6 & 20.1 & \\
\hline \multicolumn{5}{|l|}{ Gender role attitudes } \\
\hline Traditional & 26.9 & 18.8 & 3.3 & \multirow{3}{*}{0.000} \\
\hline Intermediate & 54.0 & 30.9 & 26.9 & \\
\hline Egalitarian & 19.1 & 50.3 & 69.8 & \\
\hline$n$ & 2,194 & 535 & 1,388 & \\
\hline
\end{tabular}

Source: Estonian and Russian GGS 2004-2005, own calculations

\section{Results}

\subsection{Intentions to become a mother}

We begin by presenting the results pertaining to childless women. Table 4 displays the modelling results in the form of odds ratios, produced as maximum likelihood estimates of parameter effects. The presentation of the findings centres on the main 
independent variable. The results for the control variables are presented in detail later in the article (Section 6.4).

In the upper part of the table, we compare the odds ratios of the intention to become a mother among currently childless Russian women in Estonia with those of their counterparts in the sending and host populations. In accord with the descriptive measures reported in the previous section, the results indicate that the differences between the three groups are relatively small. In the initial model (M1), Russians who have settled in Estonia tend to exhibit only slightly higher odds of intention to become a parent than the host population and Russians in the country of origin. The pattern reverses as various controls are added, but none of the differences between the groups reach the level of statistical significance.

Tab. 4: Odds ratios for intention to become a mother (logistic regression models). Russians in Estonia, sending and host populations, childless women, aged 20-44

\begin{tabular}{lcccc}
\hline Population groups & $\mathrm{M} 1$ & $\mathrm{M} 2$ & $\mathrm{M} 3$ & $\mathrm{M} 4$ \\
\hline Russians in Russia & 0.91 & 1.34 & 1.37 & 1.24 \\
Russians in Estonia (ref.) & 1.00 & 1.00 & 1.00 & 1.00 \\
Estonians & 0.93 & 1.12 & 1.21 & 1.09 \\
Russians in Russia & 0.78 & 1.29 & 1.33 & 1.18 \\
$1^{\text {st }}$ generation Russians in Estonia & 0.31 & 0.81 & 0.85 & 0.75 \\
$2^{\text {nd+ generation Russians in Estonia (ref.) }}$ & 1.00 & 1.00 & 1.00 & 1.00 \\
Estonians & 0.79 & 1.08 & 1.17 & 1.04 \\
$\mathrm{n}$ & 925 & 925 & 925 & 925 \\
\hline
\end{tabular}

Note: ${ }^{* *} \mathrm{p}<0.01 ;{ }^{*} \mathrm{p}<0.05 ;{ }^{*} \mathrm{p}<0.1$.

Model 1: model without socio-demographic controls.

Model 2: M1 controlled for age and partnership status.

Model 3: M2 additionally controlled for type of settlement.

Model 4: M3 additionally controlled for educational attainment.

Source: Estonian and Russian GGS 2004-2005, own calculations

The lower part of Table 4 distinguishes between first-generation Russians and their descendants who were born in the host country. Although a comparison of the odds ratios suggests a moderate shift across generations towards increased convergence with the host population, the difference between migrants and their descendants does not reach statistical significance in any model. However, the analysis is hindered by the small number of childless women among the first-generation migrants. 


\subsection{Intentions to have a second child}

Table 5 presents the modelling results for mothers' intentions to have a second child. Unlike the intended transition to first birth, the odds ratios reveal marked differences between the groups included in the study. Russians who have settled in Estonia are the least likely to consider having a second child, exhibiting lower intentions of further childbearing than their counterparts in the country of origin. The highest odds of intended transition beyond the first child are characteristic of the host population, in accord with the difference in cohort fertility between Estonia and Russia (Myrskylä et al. 2013). Overall, the intention to have a second child for Russians in Estonia bears much greater resemblance to that of their counterparts in the country of origin. Although the odds ratios vary across the models, this general pattern remains basically unaltered as socio-demographic controls are added.

Tab. 5: Odds ratios for intention to have a second child (logistic regression models). Russians in Estonia, sending and host populations, women with one child, aged 20-44

\begin{tabular}{|c|c|c|c|c|}
\hline Population groups & M1 & M2 & M3 & M4 \\
\hline Russians in Russia & $1.46 * * *$ & 1.30 & $1.43^{*}$ & $1.39 * *$ \\
\hline Russians in Estonia (ref.) & 1.00 & 1.00 & 1.00 & 1.00 \\
\hline Estonians & $2.94 * * *$ & $2.97 * * *$ & $3.48 * * *$ & $3.45^{* * *}$ \\
\hline Russians in Russia & 1.20 & 1.36 & $1.50^{*}$ & $1.45^{*}$ \\
\hline $1^{\text {st }}$ generation Russians in Estonia & $0.46^{* *}$ & 1.22 & 1.21 & 1.19 \\
\hline $2^{\text {nd+ }}$ generation Russians in Estonia (ref.) & 1.00 & 1.00 & 1.00 & 1.00 \\
\hline Estonians & $2.41 * * *$ & $3.13^{* * *}$ & $3.65^{* * *}$ & $3.61^{* * *}$ \\
\hline $\mathrm{n}$ & 1,541 & 1,541 & 1,541 & 1,541 \\
\hline
\end{tabular}

Note: ${ }^{* *} \mathrm{p}<0.01 ;{ }^{*} \mathrm{p}<0.05 ;{ }^{*} \mathrm{p}<0.1$.

Model 1: model without socio-demographic controls.

Model 2: M1 controlled for age and partnership status.

Model 3: M2 additionally controlled for type of settlement.

Model 4: M3 additionally controlled for educational attainment.

Source: Estonian and Russian GGS 2004-2005, own calculations

The evidence pertaining to migrant generations reveals considerable similarity between migrants and their descendants in the intention to have a second child. Following the inclusion of controls for basic demographic variables (age and partnership status) in Model M2, the difference between migrant generations loses the statistical significance observed in the initial model. The modelling results indicate no shift towards convergence with the host population in intentions regarding further childbearing among the descendants of Russian migrants. 


\subsection{Intentions to have a third child}

Given the strength of the two-child family norm in contemporary low-fertility societies (Sobotka/Beaujouan 2014), having a third child can be regarded as discretionary and dependent on individual circumstances. Nevertheless, our results show a noticeable intergroup difference in intentions to have a third child (Table 6). Similarly to second births, the host population (Estonians) exhibits the highest odds of considering a larger family. Interestingly, however, Russians in Estonia and the sending population feature highly similar intentions to go beyond the two-child family. In the final model (M4), with all the socio-demographic controls included, the difference in the odds ratio is only 6 percent. Furthermore, the comparison of results across models indicates the robustness of this finding, as the odds ratio for the sending population (Russians in Russia) does not attain the level of statistical significance in any of them.

Tab. 6: Odds ratios for intention to have a third child (logistic regression models). Russians in Estonia, sending and host populations, women with two children, aged 20-44

\begin{tabular}{|c|c|c|c|c|}
\hline Population groups & M1 & M2 & M3 & M4 \\
\hline Russians in Russia & 0.92 & 0.87 & 0.97 & 0.94 \\
\hline Russians in Estonia (ref.) & 1.00 & 1.00 & 1.00 & 1.00 \\
\hline Estonians & $2.10 * * *$ & $1.80^{* *}$ & $2.03^{* * *}$ & $1.98^{* *}$ \\
\hline Russians in Russia & 0.78 & 0.91 & 1.02 & 0.97 \\
\hline $1^{\text {st }}$ generation Russians in Estonia & 0.61 & 1.17 & 1.18 & 1.10 \\
\hline $2^{\text {nd+ }}$ generation Russians in Estonia (ref.) & 1.00 & 1.00 & 1.00 & 1.00 \\
\hline Estonians & $1.79 * *$ & $1.88^{* *}$ & $2.12^{* *}$ & $2.04^{* *}$ \\
\hline$n$ & 1,283 & 1,283 & 1,283 & 1,283 \\
\hline
\end{tabular}

Note: ${ }^{* *} \mathrm{p}<0.01 ;{ }^{* *} \mathrm{p}<0.05 ;{ }^{*} \mathrm{p}<0.1$.

Model 1: model without socio-demographic controls.

Model 2: M1 controlled for age and partnership status.

Model 3: M2 additionally controlled for type of settlement.

Model 4: M3 additionally controlled for educational attainment.

Source: Estonian and Russian GGS 2004-2005, own calculations

\subsection{Childbearing intentions and views on gender roles}

The next step was to ascertain whether the differences in fertility intentions between the groups included in the study could be explained by factors other than the socio-demographic controls. Guided by previous research on fertility intentions and the descriptive statistics presented earlier in the article, we fitted additional models with attitudes towards gender roles included as an independent variable (M5). These models were not estimated for childless women, who, as mentioned in 
the previous sections, exhibited no statistically significant difference in childbearing intentions between migrants, the host population and the sending population.

The results displayed in Table 7 suggest that the shift away from traditional gender role attitudes relates to an increased likelihood of the intention to have another child. For women who have one or two children, the odds ratios for egalitarian gender role attitudes exceed the reference category (traditional view on gender roles) by 43 and 65 percent respectively. The difference between women who exhibit egalitarian views and those who took a more traditional stance towards gender roles appears statistically significant throughout. Elevated odds of intended further childbearing are also seen among women who were classified as having an intermediate role orientation. The difference from the reference category reached the level of statistical significance, except in the case of mothers of two children.

Tab. 7: Odds ratios for intention to have a/another child (logistic regression models). Russians in Estonia, sending and host populations, women aged $20-44$

\begin{tabular}{|c|c|c|c|c|}
\hline \multirow[t]{2}{*}{ Variables } & \multirow{2}{*}{$\begin{array}{c}\text { M4 } \\
\text { All women }\end{array}$} & \multicolumn{3}{|c|}{ M5 } \\
\hline & & All women & 1 child & 2 children \\
\hline \multicolumn{5}{|l|}{ Gender role attitudes } \\
\hline Traditional (ref.) & & 1.00 & 1.00 & 1.00 \\
\hline Intermediate & & $1.41^{* * *}$ & $1.38^{*}$ & 1.38 \\
\hline Egalitarian & & $1.50 * * *$ & $1.43^{*}$ & $1.65^{* *}$ \\
\hline \multicolumn{5}{|l|}{ Population group } \\
\hline Russians in Russia & 1.16 & 1.22 & $1.48 * *$ & 1.12 \\
\hline Russians in Estonia (ref.) & 1.00 & 1.00 & 1.00 & 1.00 \\
\hline Estonians & $2.48 * * *$ & $2.34 * * *$ & $3.25^{* * *}$ & $2.10 * * *$ \\
\hline Age & $0.81 * * *$ & $0.81 * * *$ & $0.80 * * *$ & $0.84 * * *$ \\
\hline \multicolumn{5}{|l|}{ Partnership status } \\
\hline Living with a partner & 1.15 & 1.16 & $1.37^{* *}$ & 1.19 \\
\hline No partner (ref.) & 1.00 & 1.00 & 1.00 & 1.00 \\
\hline Number of children & $0.37 * * *$ & $0.37 * * *$ & - & - \\
\hline \multicolumn{5}{|l|}{ Settlement type } \\
\hline Urban (ref.) & 1.00 & 1.00 & 1.00 & 1.00 \\
\hline Rural & $0.72 * * *$ & $0.72 * * *$ & $0.63^{* * *}$ & $0.75^{*}$ \\
\hline \multicolumn{5}{|l|}{ Educational attainment } \\
\hline Basic & 0.85 & 0.86 & $0.68^{*}$ & 1.15 \\
\hline Secondary (ref.) & 1.00 & 1.00 & 1.00 & 1.00 \\
\hline Tertiary & $1.39 * * *$ & $1.36 * * *$ & 1.26 & 1.31 \\
\hline$n$ & 4,117 & 4,117 & 1,541 & 1,283 \\
\hline
\end{tabular}

Note: ${ }^{* *} \mathrm{p}<0.01 ;{ }^{*} \mathrm{p}<0.05 ;{ }^{*} \mathrm{p}<0.1$.

Source: Estonian and Russian GGS 2004-2005, own calculations 
A significant positive relationship between egalitarian views on gender roles and fertility intentions is also revealed in Model M5, which was fitted for all parities combined. A comparison of results obtained from Models M4 and M5 suggests that differences in the spread of gender-egalitarian attitudes (see Table 3) underlie part of the variation in fertility intentions between the groups included in our study. In particular, this can be seen in the reduction of the odds ratio for Estonians from Model M4 to Model M5. However, as the reduction is moderate, varying views on gender roles are evidently responsible for only a small part of the difference in fertility intentions between Russians in Estonia, Estonians, and Russians in the country of origin.

Finally, Table 7 presents the results for the socio-demographic controls included in the models. With a few exceptions, the effects of the control variables are stable across the different models. Likewise, they exhibit patterns that are similar to those reported in comparable studies on fertility intentions (e.g. Puur et al. 2008; Miettinen et al. 2011; Nedoluzhko 2012).

\subsection{The effects of integration variables}

In order to investigate the role of the integration variables, we focus on Russian women in Estonia who have had at least one child. The selection was motivated by the results shown in Sections 5.2 and 5.3, according to which the difference in childbearing intentions between Russian migrants and their descendants, on the one hand and the host population on the other is most pronounced among parous women. In order to ascertain whether a greater degree of integration is associated with convergence of intentions to have another child, we fitted three additional models based on our final model with socio-demographic controls (M4), to which we added proficiency in the host country language (M6), composition of the population in area of residence (M7), and having an ethnic Estonian partner (M8). Owing to the small sample size and the correlation between our integration variables, we preferred to include them in the model one at a time. These additional models were fitted solely for migrants and their descendants, as the integration process is not relevant to the sending and host populations.

The results displayed in Table 8 indicate that all the integration variables considered in our study are associated with statistically significant increases in the intention to have another child. In light of the results presented earlier in the article, this means a shift away from the pattern characteristic of the sending country and towards that of the host country. In addition, the effects can be regarded as relatively strong, with odds ratios ranging from 1.8 in the case of language proficiency to 2.4 for living in areas with a large majority of host country natives. 
Tab. 8: Odds ratios for intention to have another child (logistic regression models). Russians in Estonia, women with at least one child, aged 20-44

\begin{tabular}{lccc}
\hline Variables & $\mathrm{M} 6$ & $\mathrm{M} 7$ & $\mathrm{M} 8$ \\
\hline Proficiency in host-country language & & & \\
$\quad$ Yes & $1.78^{*}$ & & \\
$\quad$ No & 1.00 & & \\
Living in area with high proportion (70+ percent) of Estonians & & \\
$\quad$ Yes & & $2.38^{*}$ & \\
$\quad$ No & & & \\
Having an Estonian partner & & & 2.00 \\
$\quad$ Yes & & & 1.00 \\
$\quad$ No & 373 & 373 & 373 \\
$\mathrm{n}$ &
\end{tabular}

Note: ${ }^{* *} \mathrm{p}<0.01 ;{ }^{*} \mathrm{p}<0.05 ;{ }^{*} \mathrm{p}<0.1$.

Model 6: M4 (explained in table 7) additionally controlled for host-country language proficiency.

Model 7: M4 additionally controlled for population composition in the municipality of residence.

Model 8: M4 additionally controlled for partnering with native Estonian.

Source: Estonian GGS 2004-2005, own calculations

\section{Summary and discussion of the findings}

In this article, we examined childbearing intentions among Russian migrants and their descendants in Estonia. Although recent studies have generated much valuable knowledge about the fertility behaviour of migrants and their descendants in a number of European countries (Mussino/Strozza 2012; Krapf/Wolf 2015; Kulu/ Hannemann 2016; Andersson et al. 2017; Pailhé 2017), fertility intentions have rarely been investigated in the immigration context. Following arguments put forward in previous research (Glick 2010; Lessard-Philips et al. 2017; Baykara-Krumme/Milewski 2017), our study employed the origin-destination perspective, which, in tandem with a parity-specific approach, allowed a more versatile insight to be gained into the childbearing intentions of migrants and their descendants. Aside from the binational sample, the contribution of our study to the literature stems from the incorporation of several variables that allowed us to connect fertility intentions to differences in gender role attitudes and the degree of integration into the host society. Finally, unlike much contemporary European research on migrant fertility, our study focuses on migrants who have moved from one low-fertility setting to another. We were particularly interested in whether we could discern differences in childbearing intentions in such a context, given the persistence of below-replacement fertility in both the host country and country of origin. 
The hypotheses for our study were derived from theoretical frameworks that are commonly applied in analyses of migrant fertility (Milewski 2010; Kulu/GonzálezFerrer 2014). The findings led us to accept our first hypothesis (H1), according to which the childbearing intentions of Russians living in Estonia exhibit greater resemblance to those in the country of origin. In all the models, which revealed a significant difference among the groups included in the study, the contrast between migrants and their descendants and the host country natives was noticeably greater than that between migrants and their descendants and their ancestral country. This led to a rejection of the adaptation perspective and lent support to the cultural maintenance argument. Socialisation into the ethnic subculture rather than the culture prevailing in the host society can be seen as a mechanism that plausibly accounts for the observed outcome. This process enables norms of the country of origin to persist among migrants, irrespective of the duration of their stay in the destination country.

Our second hypothesis $(\mathrm{H} 2)$ anticipated that similarity would be found between first-generation migrants and their descendants born in the host country. The findings confirmed our expectations, as the difference between migrant generations did not reach the level of statistical significance in any of the models, which were estimated separately for childless women and those with one or two children. Even if this were due in part to the relatively small sample size, the models that were controlled for socio-demographic characteristics revealed no shift in the odds ratios of intended childbearing that would have brought the migrants' descendants closer to the host population. This finding adds further support to the cultural maintenance argument, according to which the descendants of Russian migrants in Estonia were socialised mainly into an ethnic subculture, which has permitted them to retain the norms and values guiding family behaviour that are rooted in their ancestral country. The close similarity between the proportion of Russian women in Estonia who intended to have a/another child and that observed for Russian women in the country of origin supports this explanation.

The comparison of model estimates for childless women with those of their counterparts who had one or two children led to the acceptance of our third hypothesis $(\mathrm{H} 3)$, i.e. that the contrast in intended fertility between the groups included in the study is driven by intentions to have a second or third child. This finding reinforces the notion that the norms shaping individuals' childbearing plans tend to be parity-specific, a fact that ought to be systematically considered in analyses of intended fertility. In this study, we also examined the influence of gender role attitudes as a factor shaping fertility intentions. Despite a noticeable difference in gender role attitudes between Estonia and Russia, this factor accounted for only a minor part of the variation in fertility intentions between the groups included in the study, lending minimal support to our fourth hypothesis (H4). However, the study did reveal a generally positive relationship between egalitarian views on women's and men's roles and the intention to have another child.

We ascribe the intergenerational stability of childbearing intentions to contextual features, most importantly the large size of the group (currently one quarter of the total population), its concentration in a limited number of regions, and relatively 
limited proficiency in the host country language. This explanation received support from models with integration variables. Confirming our hypothesis that improving the integration of migrants and their descendants into the host society facilitates convergence of their fertility intentions with those of the host population ( $\mathrm{H} 5)$, the models showed that proficiency in the Estonian language, residence in municipalities where Estonians constitute a large majority of the population, and having a native partner were related to significant increases in the odds of intention to have another child, i.e. closing the gap between migrants and their descendants and the host population. Although integration processes have been proceeding relatively slowly due to the reasons explained above, the findings from models with integration variables lend unambiguous support to the adaptation argument.

In accord with our final hypothesis (H6), selectivity and compositional differences were found to play a discernible role in shaping childbearing intentions among Russian migrants and their descendants in Estonia. Judging from our results for intended transitions to first, second and third births, changes in intergroup differences associated with the inclusion of socio-demographic controls in the models were relatively moderate. In most cases, these changes did not result in a loss or gain of statistical significance. A systematic decrease in intergroup differences followed the inclusion of basic demographic variables in the models. This likely arose from the fact that the first-generation migrants were on average older than the other groups included in our study. Another compositional effect, related to the high concentration of migrants in urban settlements, could be discerned for the intention to have a second child. However, contrary to expectations, the difference in the odds of second birth increased rather than diminished after including a control for settlement type. With regard to educational attainment, the inclusion of the latter control variable slightly for all the intended parity transitions investigated in this study diminished the difference between Russians in Estonia, on the one hand, and the sending and host populations, on the other hand.

Somewhat surprisingly, in our analysis the intentions of Russians in Estonia to have a second child did not fall in the range between those of the sending and host populations. Given the less favourable economic position of Russian migrants in Estonia (Lindemann 2013; Saar/Helemäe 2017), it can be assumed that greater economic uncertainty might have contributed to this pattern. In order to test this assumption we included some additional controls in the models, such as labour market status and income. Since these controls did not affect the above pattern, another explanation must be sought in lieu of economic uncertainty. However, delving into this issue is beyond the focus of our article.

Admittedly, this study is not devoid of limitations, which stem from various sources. A relatively small sample size, particularly for migrants, prevented us from estimating more elaborate models that would have, for instance, allowed us to distinguish those who had arrived in the host country as children (the 1.5 generation) from the rest of the first generation. Another limitation of this study relates to the focus on women. Previous research has demonstrated that gender equality does not have a uniform effect on childbearing intentions, but rather that the impact varies considerably by gender, parity and the ways in which gender equality is con- 
ceptualised and measured (Goldscheider et al. 2010; Neyer et al. 2013). Therefore, the omission of men may have provided a one-sided account of the relationship between attitudes towards gender roles and fertility intentions. A further drawback of the study arises from the fact that the empirical data were collected more than a decade ago (from 2004 to 2005). As a consequence, the progress that the younger generations of descendants of Russians have made in integrating into the host society is not discernible in our results. Finally, we did not investigate the realisation of childbearing intentions among the groups included in the study. These are all worthy topics of future research.

In summary, what general conclusions can then be drawn from this study? First, our results suggest that the cultural maintenance and adaptation perspectives, developed and widely used in the context of fertility behaviour, can be employed in the study of fertility intentions as well. Likewise, our study confirms that these perspectives are applicable to migrant groups who move from one low-fertility setting to another, with relatively small differences in fertility levels between the sending and host populations. Second, the comparison of results with those of a recent study that focussed on transitions to first, second and third births among the same group of migrants (Puur et al. 2017) reveals considerable similarity between actual and intended fertility. In a broader framework, the observed similarity lends support to the view that factors influencing fertility intentions largely coincide with those shaping actual childbearing (Rindfuss et al. 1988; Schoen et al. 1999). Third, for the host society (Estonia) our study predicts that the difference in fertility rates between Russian migrants and their descendants, and the host population is likely to persist in the short term. However, successful integration policies can be expected to increase the rates of second and third births among Russians in Estonia over the long term and thus have a positive effect on the overall fertility level of the country. Fourth, our findings showing a positive relationship between more egalitarian attitudes towards gender roles and intentions to have a second or third child lend support to arguments claiming that the progress of the gender revolution may contribute to the gradual recovery of fertility rates in low-fertility settings (EspingAndersen/Billari 2015; Goldscheider et al. 2015).

\section{Acknowledgement}

We thank Nadja Milewski, Eleonora Mussino, Katrin Schiefer and two anonymous reviewers for their helpful comments and advice during the writing of this article. This undertaking was supported by the Estonian Research Council (Grant PRG71).

\section{References}

Abbasi-Shavazi, Mohammad Jalal; McDonald, Peter 2000: Fertility and Multiculturalism: Immigrant Fertility in Australia, 1977-1991. In: International Migration Review 34,1: 215-242 [doi: 10.2307/2676018]. 
Abbasi-Shavazi, Mohammad Jalal; McDonald, Peter 2002: A Comparison of Fertility Patterns of European Immigrants in Australia with Those in The Countries of Origin. In: Genus 58,1: 53-76.

Abuladze, Liili et al. 2013: Migration Effects of Fertility. The Case of Russian Migrants in Estonia. Paper presented at IUSSP XXVII International Population Conference, Busan, South Korea, August 26-31, 2013.

Alba, Richard 2005: Bright vs. Blurred Boundaries: Second-generation Assimilation and Exclusion in France, Germany, and the United States. In: Ethnic and Racial Studies 28,1: 20-49 [doi: 10.1080/0141987042000280003].

Algan, Yann et al. (Eds.) 2012: Cultural integration of immigrants in Europe. Oxford: Oxford University Press.

Andersson, Gunnar 2004: Childbearing after Migration: Fertility Patterns of Foreignborn Women in Sweden. In: International Migration Review 38,2: 747-774 [doi: 10.1111/ j.1747-7379.2004.tb00216.x].

Andersson, Gunnar; Scott, Kirk 2007: Childbearing Dynamics of Couples in a Universalistic Welfare State: The Role of Labor-market Status, Country of Origin, and Gender. In: Demographic Research 17,30: 897-938 [doi: 10.4054/DemRes.2007.17.30].

Andersson, Gunnar; Persson, Lotta; Obućina, Ognjen 2017: Depressed Fertility among Descendants of Immigrants in Sweden. In: Demographic Research 36,39: 1149-1184 [doi: 10.4054/DemRes.2017.36.39].

Bagavos, Christos; Tsimbos, Cleon; Verropoulou, Georgia 2008: Native and Migrant Fertility Patterns in Greece: A Cohort Approach. In: European Journal of Population 24,3: 245-263 [doi: 10.1007/s10680-007-9142-6].

Baizán, Pau; Beauchemin, Cris; González-Ferrer, Amparo 2014: An Origin and Destination Perspective on Family Reunification: The Case of Senegalese Couples. In: European Journal of Population 30,1: 65-87.

Balbo, Nicoletta; Billari, Francesco C.; Mills, Melinda 2013: Fertility in Advanced Societies: A Review of Research. In: European Journal of Population 29,1: 1-38 [doi: 10.1007/ s10680-012-9277-y].

Baykara-Krumme, Helen; Milewski, Nadja 2017: Fertility Patterns among Turkish Women in Turkey and Abroad: The Effects of International Mobility, Migrant Generation, and Family Background. In: European Journal of Population 33,3: 409-439 [doi: 10.1007/ s10680-017-9413-9].

Bean, Frank D.; Swicegood, C. Gray; Berg, Ruth 2000: Mexican-origin Fertility: New Patterns and Interpretations. In: Social Science Quarterly 81,1: 404-420.

Billingsley, Sunnee; Puur, Allan; Sakkeus, Luule 2014: Jobs, Careers, and Becoming a Parent under State Socialist and Market Conditions: Evidence from Estonia 1971-2006. In: Demographic Research 30,64: 1733-1768 [doi: 10.4054/DemRes.2014.30.64].

Bongaarts, John 2001: Fertility and Reproductive Preferences in Post-transitional Societies. In: Population and Development Review 27 (Supplement: Global fertility transition): $260-281$.

Brewster, Karin L.; 1994: Race Differences in Sexual Activity among Adolescent Women: The Role of Neighborhood Characteristics. In: American Sociological Review 59,1: 408-424 [doi: 10.2307/2095941].

Coleman, David A.; 1994: Trends in Fertility and Intermarriage among Immigrant Populations in Western-Europe as Measure of Integration. In: Journal of Biosocial Science 26,1: 107-136 [doi: 10.1017/S0021932000021106]. 
Cygan-Rehm, Kamila 2011: Between Here and There: Immigrant Fertility Patterns in Germany. BGPE Discussion Paper 109. Bavarian Graduate Program in Economics.

de Valk, Helga; Milewski, Nadja (Eds.) 2011: Family Life Transitions of the Second Generation. In: Advances of Life Course Research 16,4: 145-218.

Dubuc, Sylvie 2012: Immigration to the UK from High-fertility Countries: Intergenerational Adaptation and Fertility Convergence. In: Population and Development Review 38,2: 353-368 [doi: 10.1111/j.1728-4457.2012.00496.x].

Espenberg, Kerli et al. 2013: Vähemusrahvustest inimeste töö- ja pereelu ühitamise võimaluste analüüs 2013 [Analysis of Work-family Balance among Ethnic Minorities 2013]. Tartu: Tartu Ülikooli sotsiaalteaduslike rakendusuuringute keskus RAKE koostöös Tartu Ülikooli sotsioloogia ja sotsiaalpoliitika instituudiga.

Esping-Andersen, Gøsta; Billari, Francesco C. 2015: Re-theorizing Family Demographics. In: Population and Development Review 31,1: 1-31 [doi: 10.1111/j.17284457.2015.00024.x].

Eurostat 2018: Census database [https://ec.europa.eu/eurostat/web/population-and-housing-census/census-data/database, 10.12.2018].

Fernandez, Raquel; Fogli, Alessandra 2006: Fertility: The Role of Culture and Family Experience. In: Journal of the European Economic Association 4,2-3: 552-561 [doi: 10.1162/jeea.2006.4.2-3.552].

Ford, Kathleen 1990: Duration of Residence in the United States and the Fertility of U.S. Immigrants. In: International Migration Review 24,1: 34-68 [doi: 10.2307/2546671].

Forste, Renata; Tienda, Marta 1996: What's Behind Racial and Ethnic Fertility Differentials? In: Population and Development Review 22 (Supplement: Fertility in the United States; New patterns, new theories): 109-133.

Frank, Reanne; Heuveline, Patrick 2005: A Cross-over in Mexican and Mexican-American Fertility Rates: Evidence and Explanations for an Emerging Paradox. In: Demographic Research 12,4: 77-104 [doi: 10.4054/DemRes.2005.12.4].

Frejka, Tomas; Zakharov, Sergei 2012: Comprehensive Analyses of Fertility Trends in the Russian Federation During the Past Half Century. MPIDR working paper WP-2012-027. Rostock: Max Planck Institute for Demographic Research.

Garssen, Joop; Nicolaas, Han 2008: Fertility of Turkish and Moroccan Women in the Netherlands: Adjustment to Native Level within one Generation. In: Demographic Research 19,33: 1249-1280 [doi: 10.4054/DemRes.2008.19.33].

Glick, Jennifer E. 2010: Connecting Complex Processes: A Decade of Research on Immigrant Families. In: Journal of Marriage and the Family 72,3: 498-515 [doi: 10.1111/j.17413737.2010.00715.x].

Goldscheider, Frances; Oláh, Livia Sz.; Puur, Allan 2010: Reconciling Studies of Men's Gender Attitudes and Fertility: Response to Westoff and Higgins. In: Demographic Research 22,8: 189-198 [doi: 10.4054/DemRes.2010.22.8].

Goldscheider, Frances; Bernhardt, Eva; Lappegård, Trude 2015: The Gender Revolution: A Framework for Understanding Changing Family and Demographic Behavior. In: Population and Development Review 41,2: 207-239 [doi: 10.1111/j.1728-4457.2015.00045.x].

Goldstein, Sidney; Goldstein, Alice 1984: Inter-relations between Migration and Fertility - Their Significance for Urbanization in Malaysia. In: Habitat International 8,1: 93-103 [doi: 10.1016/0197-3975(84)90030-4].

Hakim, Catherine 2005: Sex Differences in Work-life Balance. In: Houston, Diane (Ed.): Work-life balance in the $21^{\text {st }}$ century. Houndmills: Palgrave MacMillan: 55-79. 
Hill, Laura E.; Johnson, Hans P. 2004: Fertility Changes among Immigrants: Generations, Neighborhoods, and Personal Characteristics. In: Social Science Quarterly 85,3: 811-826 [doi: 10.1111/j.0038-4941.2004.00246.x].

Hirschman, Charles 1983: America's Melting Pot Reconsidered. In: Annual Review of Sociology 9: 397-423 [doi: 10.1146/annurev.so.09.080183.002145].

Hotz, V. Joseph; Klerman, Jacob Alex; Willis, Robert J. 1997: The Economics of Fertility in Developed Countries. In: Rosenzweig, Mark R.; Stark, Oded (Eds.): Handbook of population and family economics. Amsterdam: Elsevier: 275-347.

Independent Institute for Social Policy 2004: Generations and Gender Survey: Fieldwork in Russia. Technical Report to the Main Study. Moscow: Independent Institute for Social Policy.

Jasilioniene, Aiva; Stankuniene, Vlada; Jasilionis, Domantas 2014: Census-linked Study on Ethnic Fertility Differentials in Lithuania. In: Studies of Transition States and Societies 6,2: 57-67.

Kahk, Juhan; Tarvel, Enn 1997: An Economic History of the Baltic Countries. Stockholm: Almquist and Wiksell International.

Kahn, Joan R. 1988: Immigrant Selectivity and Fertility Adaptation in the United States. In: Social Forces 67,1: 108-128 [doi: 10.2307/2579102].

Katus, Kalev 1990: Demographic Trends in Estonia Throughout the Centuries. In: Yearbook of Population Research in Finland 28: 50-66.

Katus, Kalev 2000: General Patterns of Post-transitional Fertility in Estonia. In: Trames 4,3: 213-230.

Katus, Kalev; Puur, Allan; Sakkeus, Luule 2002: Immigrant Population in Estonia. In: Haug, Werner; Compton, Paul; Courbage, Youssef (Eds.): The Demographic Characteristics of Immigrant Population in Europe. Strasbourg: Council of Europe Publishing: 131-192.

Katus, Kalev; Puur, Allan; Sakkeus Luule 2008: Family Formation in the Baltic Countries: A Transformation in the Legacy of State Socialism. In: Journal of Baltic Studies 39,2: 123-156 [doi: 10.1080/01629770802031218].

Kaufman, Gayle 2000: Do Gender Role Attitudes Matter? In: Journal of Family Issues 21,1: 128-144.

Klimek, Łukasz 2017: Migration and Fertility. Polish Migrant Families in Ireland and Nonmigrant Families in Poland: A Comparison of Fertility Plans and Behaviour. In: Central and Eastern European Migration Review 6,2: 5-30 [doi: 10.17467/ceemr.2017.19].

Krapf, Sandra; Wolf, Katharina 2015: Persisting Differences or Adaptation to German Fertility Patterns? First and Second Birth Behavior of the 1.5 and Second Generation Turkish Migrants in Germany. In: Kölner Zeitschrift für Soziologie und Sozialpsychologie 67 (Suppl): 137-164 [doi: 10.1007/s11577-015-0331-8].

Kraus, Elisabeth, K.; Castro-Martín, Teresa 2018: Does Migrant Background Matter for Adolescents' Fertility Preferences? The Latin American 1.5 Generation in Spain. In: European Journal of Population 34,3: 277-312 [doi: 10.1007/s10680-017-9427-3].

Kulu, Hill 2005: Migration and Fertility: Competing Hypotheses Re-examined. In: European Journal of Population 21,1: 51-87 [doi: 10.1007/s10680-005-3581-8].

Kulu, Hill; González-Ferrer, Amparo 2014: Family Dynamics among Immigrants and their Descendants in Europe: Current Research and Opportunities. In: European Journal of Population 30,4: 411-435 [doi: 10.1007/s10680-014-9322-0]. 
Kulu, Hill; Hannemann, Tina 2016: Why Does Fertility Remain High among Certain UK-born Ethnic Minority Women? In: Demographic Research 35,49: 1441-1488 [doi: 10.4054/DemRes.2016.35.49].

Kulu, Hill; Milewski, Nadja 2007: Family Change and Migration in the Life Course: An Introduction. In: Demographic Research 17,19: 567-590 [doi: 10.4054/DemRes.2007.17.19].

Kulu, Hill et al. 2017: Fertility by Birth Order among the Descendants of Immigrants in Selected European Countries. In: Population and Development Review 43,1: 31-60 [doi: 10.1111/padr.12037].

Lanzieri, Giampaolo 2011: Fewer, Older and Multicultural? Projections of the EU Populations by Foreign/national Background. Luxembourg: Publications Office of the European Union.

Lessard-Phillips, Laurence et al. 2017: Damned If You Do, Damned If You Don't: The Challenges of Including and Comparing the Children of Immigrants in European Survey Data. In: Bolzman, Claudio; Bernardi, Laura; Le Goff, Jean-Marie (Eds.): Situating Children of Migrants across Borders and Origins. In: Life Course Research and Social Policies 7: 25-53 [doi: 10.1007/978-94-024-1141-6_2].

Lesthaeghe, Ron 2010: The Unfolding Story of the Second Demographic Transition. In: Population and Development Review 36,2: 211-251 [doi: 10.1111/j.17284457.2010.00328.x].

Lievens, John 1999: Family-formation Migration from Turkey and Morocco to Belgium: The Demand for Marriage Partners from the Countries of Origin. In: International Migration Review 33,3: 717-744 [doi: 10.2307/2547532].

Lindemann, Kristina 2013: Structural Integration of Young Russian-speakers in Post-Soviet Contexts: Educational Attainment and the Transition to the Labour Market. Dissertations in Social Sciences 68 (PhD thesis). Tallinn: Tallinn University.

Lindstrom, David; Saucedo, Giorguli S. 2002: The Short- and Long-term Effects of U.S. Migration Experience on Mexican Women's Fertility. In: Social Forces 80,4: 1341-1368 [doi: 10.1353/sof.2002.0030].

Macisco, John J.; Bouvier, Leon F.; Weller, Robert H. 1970: Effect of Labour Force Participation on the Relation between Migration Status and Fertility in San-Juan, PuertoRico. In: Milbank Memorial Fund Quarterly 48,1: 51-70 [doi: 10.2307/3349288].

Marczak, Joanna 2013: Childbearing Intentions of Polish Nationals in Poland and in the UK: Progression to the Second Child (Ph.D. thesis). London: London School of Economics and Political Science.

Mayer, Jochen; Riphahn, Regina T. 2000: Fertility Assimilation of Immigrants: Evidence from Count Data Models. In: Journal of Population Economics 13,2: 241-261 [doi: 10.1007/s001480050136].

McDonald, Peter 2000: Gender Equity in Theories of Fertility Transition. In: Population and Development Review 26,3: 427-439 [doi: 10.1111/j.1728-4457.2000.00427.x].

McDonald, Peter 2013: Societal Foundations for Explaining Low Fertility: Gender Equity. In: Demographic Research 28,34: 981-994 [doi: 10.4054/DemRes.2013.28.34].

Miettinen, Anneli; Gietel-Basten, Stuart; Rotkirch, Anna 2011: Gender Equality and Fertility Intentions Revisited: Evidence from Finland. In: Demographic Research 24,20: 469-496 [doi: 10.4054/DemRes.2011.24.20].

Milewski, Nadja 2007: First Child of Immigrant Workers and their Descendants in West Germany: Interrelation of Events, Disruption, or Adaptation? In: Demographic Research 17,29: 859-896 [doi: 10.4054/DemRes.2007.17.29]. 
Milewski, Nadja 2010: Immigrant Fertility in West Germany: Is There a Socialization Effect in Transitions to Second and Third Births? In: European Journal of Population 26,3: 297-323 [doi: 10.1007/s10680-010-9211-0].

Milewski, Nadja 2011: Transition to a First Birth among Turkish Second-generation Migrants in Western Europe. In: Advances in Life Course Research 16,4: 178-189 [doi: 10.1016/j.alcr.2011.09.002].

Mills, Melinda 2010: Gender Roles, Gender (In)equality and Fertility: An Empirical Test of Five Gender Equity Indices. In: Canadian Population Studies 37,3-4: 445-474 [doi: 10.25336/P61310].

Morgan, Philip; Rackin, Heather 2010: The Correspondence between Fertility Intentions and Behavior in the United States. In: Population and Development Review 36,1: 91118 [doi: 10.1111/j.1728-4457.2010.00319.x].

Mönkediek, Bastian; Bras, Hilde 2016: Family Systems and Fertility Intentions: Exploring the Pathways of Influence. In: European Journal of Population 34,1: 33-57 [doi: 10.1007/s10680-017-9418-4].

Mussino, Eleonora; Strozza, Salvatore 2012: The Fertility of Immigrants after Arrival: The Case of Italy. In: Demographic Research 26,4: 99-130 [doi: 10.4054/DemRes.2012.26.4].

Myrskylä, Mikko; Goldstein, Joshua R.; Cheng, Yen-hsin Alice 2013: New Cohort Fertility Forecasts for the Developed World: Rises, Falls, and Reversals. In: Population and Development Review 39,1: 31-56 [doi: 10.1111/j.1728-4457.2013.00572.x].

Nauck, Bernhard 2007: Immigrant Families in Germany: Family Change between Situational Adaptation, Acculturation, Segregation and Remigration. In: Zeitschrift fur Familienforschung 19,1: 34-54.

Nedoluzhko, Lesia 2012: Achieved Fertility and Fertility Intentions among Ethnic Groups in Central Asia: Kyrgyzstan, Taijkistan, and Uzbekistan Compared. Stockholm Research Reports in Demography 2012-4. Stockholm: Stockholm University.

Neyer, Gerda; Lappegard, Trude; Vignoli, Daniele 2013: Gender Equality and Fertility: Which Equality Matters? In: European Journal of Population 29,3: 245-272 [doi: 10.1007/s10680-013-9292-7].

Pailhé, Ariane 2017: The Convergence of Second-generation Immigrants' Fertility Patterns in France: The Role of Sociocultural Distance between Parents' and Host Country. In: Demographic Research 36,45: 1361-1398 [doi: 10.4054/DemRes.2017.36.45].

Parrado, Emilio A.; Morgan, S. Philip 2008: Intergenerational Fertility Among Hispanic Women: New Evidence of Immigrant Assimilation. In: Demography 45,3: 651-671 [doi: 10.1353/dem.0.0023].

Pessin, Léa; Arpino, Bruno 2018: Navigating between Two Cultures: Immigrants' Gender Attitudes towards Working Women. In: Demographic Research 38,35: 967-1016 [doi: 10.4054/DemRes.2018.38.35].

Philipov, Dmiter 2009: Fertility Intentions and Outcomes: The Role of Policies to Close the Gap. In: European Journal of Population 25,4: 355-361 [doi: 10.1007/s10680-0099202-1].

Philipov, Dmiter; Bernardi, Laura 2011: Concepts and Operationalisation of Reproductive Decisions. Implementation in Austria, Germany and Switzerland. In: Comparative Population Studies 36,2-3: 495-530 [doi: 10.4232/10.CPoS-2011-14en].

Philipov, Dmiter; Spéder, Zsolt; Billari, Francesco C. 2006: Soon, Later, or Ever? The Impact of Anomie and Social Capital on Fertility Intentions in Bulgaria (2002) and Hungary (2001). In: Population Studies 60,3: 289-308 [doi: 10.1080/00324720600896080]. 
Puur, Allan et al. 2008: Men's Childbearing Desires and Views of the Male Role in Europe at the Dawn of the $21^{\text {st }}$ Century. In: Demographic Research 19,56: 1883-1912 [doi: 10.4054/DemRes.2008.19.56].

Puur, Allan et al. 2012: Transformation of Partnership Formation in Eastern Europe: The Last of Past Demographic Divide. In: Journal of Comparative Family Studies 43,3: 389-418.

Puur, Allan; Klesment, Martin 2012: Signs of Stable or Provisional Increase in fertility? Reflections on Developments in Estonia. In: Demográfia 54,5: 31-55.

Puur, Allan; Rahnu, Leen; Valge, Jaak 2016: Eesti keel sisserändetuultes (I). Demograafiline tagasivaade 1989-2011 ja edasipilk [Estonian Language in the Winds of Immigration (I): A Demographic Retrospective 1989-2011 and a Look Forward]. In: Keel ja Kirjandus 59,4: 268-280.

Puur, Allan et al. 2017: Childbearing among First- and Second-generation Russians in Estonia against the Background of Sending and Host Countries. In: Demographic Research 36,41: 1209-1254 [doi: 10.4054/DemRes.2017.36.41].

Puur, Allan et al. 2018: The Formation of Ethnically Mixed Partnerships in Estonia: A Stalling Trend from a Two-sided Persepective. In: Demographic Research 38,38: 11111154 [doi: 10.4054/DemRes.2018.38.38].

Quesnel-Vallée, Amélie; Morgan, S. Philip 2003: Missing the Target? Correspondence of Fertility Intentions and Behavior in the U.S. In: Population Research and Policy Review 22,5-6: 497-525 [doi: 10.1023/B:POPU.0000021074.33415.c1].

Rahnu, Leen et al. 2015: Dynamics of Mixed Partnerships in Estonia. In: FamiliesAndSocieties working paper 57. Stockholm: Stockholm University: 63-112.

Rahnu, Leen 2016: Partnership Dynamics in Second Half of the $20^{\text {th }}$ Century: Evidence from Estonia and Other GGS Countries of Europe. Dissertations in Social Sciences 103 (PhD thesis). Tallinn: Tallinn University.

Realo, Anu 2017: Immigration and Intergration. In: Tammaru, Tiit; Eamets, Raul; Kallas, Kristina (Eds.): Human Development Report 2016/2017. Estonia in the Age of Migration. Tallinn: Eesti Koostöö Kogu: 117-122.

Reher, David Sven 1998: Family Ties in Western Europe: Persistent Contrasts. In: Population and Development Review 24,2: 203-234 [doi: 10.2307/2807972].

Rindfuss, Ronald R.; Morgan, Philip S.; Swicegood, Gray 1988: First Births in America: Changes in the Timing of Parenthood. Berkeley: University of California Press.

Rumbaut, Rubén G.; Weeks, John R. 1986: Fertility and Adaptation: Indochinese Refugees in the United States. In: International Migration Review 20,2: 428-466 [doi: 10.2307/2546043].

Saar, Ellu; Helemäe, Jelena 2017: Ethnic Segregation in the Estonian Labour Market. In: Tammaru, Tiit; Eamets, Raul; Kallas, Kristina (Eds.): Human Development Report 2016/2017. Estonia in the Age of Migration. Tallinn: Eesti Koostöö Kogu: 147-154.

Schoen, Robert et al. 1999: Do Fertility Intentions Affect Fertility Behaviour? In: Journal of Marriage and the Family 61,3: 790-799 [doi: 10.2307/353578].

Schoenmaeckers, Ronald C.; Lodewijckx, Edith; Gadeyne, Sylvie 1999: Marriages and Fertility among Turkish and Moroccan Women in Belgium: Results from Census Data. In: International Migration Review 33,4: 901-928 [doi: 10.2307/2547357].

Scott, Kirk; Stanfors, Maria 2011: The Transition to Parenthood among the Second Generation: Evidence from Sweden, 1990-2005. In: Advances in Life Course Research 16,4: 190-204 [doi: 10.1016/j.alcr.2011.09.003]. 
Sobotka, Tomáš 2008: The Rising Importance of Migrants for Childbearing in Europe. In: Demographic Research 19,9: 225-248 [doi: 10.4054/DemRes.2008.19.9].

Sobotka, Tomáš; Beaujouan, Éva 2014: Two is Best? The Persistence of a Two-child Family Ideal in Europe. In: Population and Development Review 40,3: 391-419 [doi: 10.1111/j.1728-4457.2014.00691.x].

Spéder, Zsolt; Kapitány, Balázs 2009: How are Time-dependent Childbearing Intentions Realized? Realization, Postponement, Abandonment, Bringing Forward. In: European Journal of Population 25,4: 503-523 [doi: 10.1007/s10680-009-9189-7].

Stichnoth, Holger; Yeter, Mustafa 2013: Cultural Influences on the Fertility Behaviour of First- and Second-generation Immigrants in Germany. ZEW Discussion Paper 13-023 Mannheim: Zentrum für Europäische Wirtschaftsforschung.

Statistical Office of Estonia 2018: Electronic database [www.stat.ee, 11.12.2018].

Tammur, Alis; Puur, Allan; Tammaru, Tiit 2017: Is There a Migration Turnaround Taking Place in Estonia? In: Tammaru, Tiit; Eamets, Raul; Kallas, Kristina (Eds.): Human Development Report 2016/2017. Estonia in the Age of Migration. Tallinn: Eesti Koostöö Kogu: 33-40.

Turner, Charles; Martin, Elizabeth 1984: Surveying Subjective Phenomena 1-2. Russell Sage: New York.

Turu-uuringute AS 2016: Soolise võrdõiguslikkuse monitooring 2016. Elanikkonna küsitlusuuringu raport [Gender Equality Monitoring 2016. A Survey Report] Tallinn: Turuuuringute AS.

UNECE 2005: Generations and Gender Programme: Survey Instruments. New York/Geneva: United Nations.

Vikat, Andres et al. 2007: Generations and Gender Survey (GGS): Towards a Better Understanding of Relationships and Processes in the Life Course. In: Demographic Research 17,14: 389-440 [doi: 10.4054/DemRes.2007.17.14].

Westoff, Charles F. 1990: Reproductive Intentions and Fertility Rates. In: International Family Planning Perspectives 16,3: 84-89 [doi: 10.2307/2133304].

Westoff, Charles F.; Higgins, Jenny 2009: Relationships between Men's Gender Attitudes and Fertility: Response to Puur et al.'s "Men's Chilbearing Desires and Views of the Male Role in Europe at the Dawn of the 21 $1^{\text {st }}$ Century". In: Demographic Research 21,3: 65-74 [doi: 10.4054/DemRes.2009.21.3].

White, Kari Lyn 2011: Determinants of Fertility across Context: A Comparison of Mexican and Turkish Immigrant Women. Doctoral dissertation, University of Texas at Austin.

Wilson, Ben; Kuha, Jouni 2016: What is the Influence of Childhood Exposure to Cultural Norms: The Role of Segregation and Community Composition in Explaining to Migrant Fertility. Paper presented at the European Population Conference, Mainz, Germany, August 31 - September 3, 2016.

Wolf, Katharina; Mulder, Clara, H. 2018: Comparing the Fertility of Ghanaian Migrants in Europe with Nonmigrants in Ghana. In: Population Space and Place 2018; e2171 [doi: 10.1002/psp.2171].

Zakharov, Sergei V. 2003: Демографический переход и воспроизводство поколений в России [Demographic Transition and generations replacement in Russia]. In: Voprosy Statistiki 11: 3-12.

Zakharov, Sergei 2008: Russian Federation: From the First to Second Demographic Transition. In: Demographic Research 19,24: 907-972 [doi: 10.4054/DemRes.2008.19.24]. 
Zakharov, Sergei V. 2017: Население России 2016 [Population of Russia 2016]. Moscow: Publishing House of Higher School of Economics.

Allan Puur, Liili Abuladze ( $\varangle)$. Estonian Institute for Population Studies, Tallinn University. Tallinn, Estonia. E-mail: allan.puur@tlu.ee, liili@tlu.ee

URL: https://www.etis.ee/Portal/Persons/Display/8aa22d50-e43c-4f54-aa88-73a91251d Ofc?PersonVID $=38008$ \&lang $=E N G$

URL: https://www.etis.ee/CV/Liili_Abuladze/eng?lang=ENG

Hanna Vseviov. Ministry of Social Affairs, Department of children and families.

Estonian Institute for Population Studies, Tallinn University. Tallinn, Estonia.

E-mail: hanna.vseviov@sm.ee, hanna.vseviov@tlu.ee 


\section{Comparative Population Studies}

WWW.comparativepopulationstudies.de

ISSN: 1869-8980 (Print) - 1869-8999 (Internet)

\section{Published by}

Prof. Dr. Norbert F. Schneider

Federal Institute for Population Research D-65180 Wiesbaden / Germany

\section{(cc) BY-SA}

2018

\section{Managing Editor}

Dr. Katrin Schiefer

\section{Copy Editor}

Dr. Evelyn Grünheid

Dr. Katrin Schiefer

\section{Editorial Assistant}

Beatriz Feiler-Fuchs

Wiebke Hamann

\section{Layout \\ Beatriz Feiler-Fuchs \\ E-mail:cpos@bib.bund.de}

\section{Scientific Advisory Board}

Karsten Hank (Cologne)

Michaela Kreyenfeld (Berlin)

Marc Luy (Vienna)

Peter Preisendörfer (Mainz)

Nikola Sander (Wiesbaden)

Zsolt Spéder (Budapest)

Rainer Wehrhahn (Kiel)

\section{Board of Reviewers}

Martin Abraham (Erlangen)

Laura Bernardi (Lausanne)

Hansjörg Bucher (Bonn)

Claudia Diehl (Konstanz)

Andreas Diekmann (Zurich)

Gabriele Doblhammer-Reiter (Rostock)

Jürgen Dorbritz (Wiesbaden)

Anette Eva Fasang (Berlin)

E.-Jürgen Flöthmann (Bielefeld)

Alexia Fürnkranz-Prskawetz (Vienna)

Beat Fux (Salzburg)

Joshua Goldstein (Berkeley)

Sonja Haug (Regensburg)

Hill Kulu (Liverpool)

Aart C. Liefbroer (The Hague)

Kurt Lüscher (Konstanz)

Emma Lundholm (Umeå)

Nadja Milewski (Rostock)

Dimiter Philipov (Vienna)

Roland Rau (Rostock)

Tomáš Sobotka (Vienna)

Jeroen Spijker (Barcelona)

Olivier Thévenon (Paris)

Helga de Valk (Brussels)

Heike Trappe (Rostock)

Michael Wagner (Cologne) 